\title{
Suppressing dissolved hydrogen sulfide in a sewer network using chemical methods
}

\author{
Faridah Othman*, Shahram MortezaNia, Shahin Ghafari, and Soenita Hashim \\ Department of Civil Engineering, Faculty of Engineering, University of Malaya, 50603 Kuala Lumpur, Malaysia. \\ Accepted 10 June, 2011

\begin{abstract}
Corrosion process and odor emission concerns caused by $\mathrm{H}_{2} \mathrm{~S}$ are a constant focus for many sewage system municipalities, usually from the first day of system operation. This study investigates the effect of several chemicals on prohibition of $\mathrm{H}_{2} \mathrm{~S}$ generation in sewage, where reagents were applied either individually or in combinations. Various concentrations of calcium peroxide, calcium hypochlorite, magnesium hydroxide, ferric chloride, and their combination with certain ratios were examined. Oxidation reduction potential (ORP) and $\mathrm{pH}$ were measured as the indicators for mitigation of $\mathrm{H}_{2} \mathrm{~S}$. Although both methods (adding chemicals individually or in combination) raised the ORP and pH to the safe range (that is $O R P \geq 50 \mathrm{mV}$ and $8.5 \leq \mathrm{pH} \leq 9$ ), experiments revealed that designed combination of chemicals resulted in more promising outcomes. The most cost effective combination was an admixture of $2 \mathrm{mg} \mathrm{FeCl} / \mathrm{L}$ and $2.5 \mathrm{mg} \mathrm{Mg}(\mathrm{OH})_{2} / \mathrm{L}$ with 30 min effective reaction time which could reduce the hydrogen sulfide greater than $95 \%$. This combination is a blend for only $25 \%$ of the optimum dosage of these chemicals compared to when they were used individually. As a result, the aforementioned combination saved $12 \%$ on chemical costs compared to use of calcium peroxide as the most effective individual chemical.
\end{abstract}

Key words: Hydrogen sulfide, chemical, corrosion, sewage.

\section{INTRODUCTION}

Environmental protection nowadays has become one of the most important initiatives around the world. In efforts to decrease environmental pollutants, hydrogen sulfide $\left(\mathrm{H}_{2} \mathrm{~S}\right)$ generation is important enough to make countries more concerned to prevent or remove such compound from sewage systems. Significant problems associated with hydrogen sulfide generation are corrosion of sewer concrete pipes, release of obnoxious odors to the atmosphere, toxicity to sewer workers or human health, water supply and environment pollution, influence on biological processes in sewage treatment plants, and cost escalation (US Environmental Protection Agency, 1974; Nielsen et al., 1998; WERF, 2003; Witherspoon et al., 2004). The presence of sulfide in wastewater is a result from physical, biological, and chemical processes

*Corresponding author. E-mail: faridahothman@um.edu.my, faridah_ce@yahoo.com. Tel: 603 79674584. Fax: 603 79675318. which mostly take place in the submerged portion of the sewer networks (Elmaleh et al., 1998). The highly toxic compound, $\mathrm{H}_{2} \mathrm{~S}$, can be formed in any aqueous system containing both organic matter and sulfate (Poulton et al., 2002).

Production of sulfide in sewage collection networks is mainly a result of sulfate reducing bacteria (SRB) activity. Edwards et al. (2001) proposed the following reactions for describing hydrogen sulfide generation under SRB condition in wastewater streams:

$\mathrm{SO}_{4}{ }^{-2}+2\left[\right.$ Organic Matter] $+2 \mathrm{H}_{2} \mathrm{O} \rightarrow 2 \mathrm{H}[$ Organic Matter] $\mathrm{O}^{3-}+\mathrm{H}_{2} \mathrm{~S}$

$\mathrm{S}^{-2}+2 \mathrm{H}^{+} \rightarrow \mathrm{H}_{2} \mathrm{~S}$

$\mathrm{SO}_{4}^{-2}+10 \mathrm{H}^{+} \rightarrow \mathrm{H}_{2} \mathrm{~S}+4 \mathrm{H}_{2} \mathrm{O}$

The rate of sulfide generation depends on several factors including $\mathrm{pH}$, temperature, concentration of organic materials and nutrients, sulfate concentrations, collection 
Table 1. The designed instruction of combined chemicals for addition to sewage.

\begin{tabular}{cc}
\hline Combination no. & Materials $^{\star}$ \\
\hline 1 & $25 \% \mathrm{X}_{\mathrm{FeCl} 3}$ and $25 \% \mathrm{Y}_{\mathrm{Mg}(\mathrm{OH}) 2}$ \\
2 & $25 \% \mathrm{X}_{\mathrm{FeCl} 3}$ and 37.5\% $\mathrm{Y}_{\mathrm{Mg}(\mathrm{OH}) 2}$ \\
3 & $37.5 \% \mathrm{X}_{\mathrm{FeCl} 3}$ and $25 \% \mathrm{Y}_{\mathrm{Mg}(\mathrm{OH}) 2}$ \\
4 & $37.5 \% \mathrm{X}_{\mathrm{FeCl} 3}$ and $37.5 \% \mathrm{Y}_{\mathrm{Mg}(\mathrm{OH}) 2}$ \\
5 & $25 \% \mathrm{X}_{\mathrm{FeCl} 3}$ and $25 \% \mathrm{Z}_{\mathrm{Ca}(\mathrm{ClO}) 2}$ \\
6 & $25 \% \mathrm{XeCl3}_{\mathrm{Fend}}$ and.5\% $\mathrm{Z}_{\mathrm{Ca}(\mathrm{ClO}) 2}$ \\
7 & $37.5 \% \mathrm{X}_{\mathrm{FeCl}}$ and $25 \% \mathrm{Z}_{\mathrm{Ca}(\mathrm{ClO}) 2}$ \\
8 & $37.5 \% \mathrm{X}_{\mathrm{FeCl} 3}$ and 37.5\% $\mathrm{Z}_{\mathrm{Ca}(\mathrm{ClO}) 2}$ \\
\hline
\end{tabular}

${ }^{*} \mathrm{X}_{\mathrm{FeCl}}, \mathrm{Y}_{\mathrm{Mg}(\mathrm{OH}) 2}$ and $\mathrm{Z}_{\mathrm{Ca}(\mathrm{ClO}) 2}$ are the optimum concentrations of $\mathrm{FeCl}_{3}, \mathrm{Mg}(\mathrm{OH})_{2}$ and $\mathrm{Ca}(\mathrm{ClO})_{2}$, respectively.

system parameters and performance, and ORP (ASCE, 1989; Delgado et al., 1999). Sulfide formation by sulfate reducing bacteria can be inhibited or eliminated through optimization of the environmental parameters that is ORP, $\mathrm{pH}$, dissolved oxygen (DO), and temperature (Zhang et al., 2008). For sewage systems, one of the most common alternatives to protect the environment is by controlling the formation or generation of sulfides. Several techniques are currently used by the wastewater industries worldwide, to prevent or control sulfide generation in the sewage systems, such as increasing DO concentration, chemical oxidation, iron salts and nitrate salts addition, and increasing $\mathrm{pH}$ using effective chemicals (Hobson and Yang, 2000; De Lomas et al., 2005).

Reactions between chemicals and sulfide species in sewage are complex with some damages on the sewer network. This phenomenon compels costly renovation or repair of sewer networks after a while. Hence, using effective and economical chemicals in order to remove sulfide from sewage is a cure for this predicament which will result in two advantages:

(I) Protection of networks against any corrosion and deterioration,

(II) Provision of odorless and non-toxic environment.

As such, much attention has been given to chemical technologies for sulfide control in sewage systems. As ultimate treatment, SRB activity can be inhibited by $\mathrm{pH}$ elevation using inhibitors such as $\mathrm{NaOH}, \mathrm{Mg}(\mathrm{OH})_{2}$, $\mathrm{Ca}(\mathrm{OH})_{2}$ (Nemati et al., 2001; Jefferson et al., 2002; De Lomas et al., 2005). Oxidant materials (e.g. $\mathrm{H}_{2} \mathrm{O}_{2}$, $\left.\mathrm{Ca}(\mathrm{ClO})_{2}, \mathrm{O}_{2}\right)$ chemically oxidize sulfide, thereby decreasing the amount of sulfides will be observed (Zhang et al., 2008). Moreover, addition of iron salts $\left(\mathrm{Fe}^{2+}, \mathrm{Fe}^{3+}\right)$ also removes hydrogen sulfide from the sewage which can convert $\mathrm{H}_{2} \mathrm{~S}$ in the sewage to insoluble metallic sulfides (Nielsen et al., 2005).

However, adding chemical materials is not free from disadvantages such as solid production, emission of some toxics, and their transportation and storage in plants. The chemical material addition method was applied in this work to deplete hydrogen sulfide dissolved in sewage of Kuala Lumpur. The first objective of this study was to determine the effectiveness of the chemical addition on the environmental parameters namely ORP and $\mathrm{pH}$. Secondly, the effective chemical dosages and the reaction time needed for hydrogen sulfide depletion was investigated for selected chemicals, which were applied individually or in combination. Thirdly, the cost analyses were also performed to find out the most economical chemical. The results reported herein may assist municipalities in using more effective and economical dosages of chemicals as corrosion and odor control alternatives.

\section{MATERIALS AND METHODS}

\begin{abstract}
Materials
In regard to the efficiency of chemicals and previous researches, chemical materials such as $\mathrm{Mg}(\mathrm{OH})_{2}(58.33 \%$ purity $), \mathrm{Ca}(\mathrm{ClO})_{2}$ (70\% purity), $\mathrm{FeCl}_{3}$ (95\% purity), and $\mathrm{CaO}_{2}$ (50\% purity) were selected to perform this work. After determining the optimum dosage of the mentioned chemicals, eight combinations of chemical materials $\left(\mathrm{FeCl}_{3}\right.$ with $\left(\mathrm{Mg}(\mathrm{OH})_{2}\right.$ and $\mathrm{FeCl}_{3}$ with $\left.\mathrm{Ca}(\mathrm{ClO})_{2}\right)$ as listed in Table 1 were designed for addition to the sewage samples. The raw sewage was collected from a gravity sewer network outlet receiving $90 \%$ domestic and $10 \%$ low-toxic industrial wastewater in Kuala Lumpur. Sampling was carried out during daytime and collected samples were preserved at $4^{\circ} \mathrm{C}$. Characterization was carried out after 8 to $12 \mathrm{~h}$ to provide samples with septic condition for analyses. The Thermo ECO 3-Star ORP and $\mathrm{pH}$ meter were used to measure ORP and $\mathrm{pH}$ for a duration of $90 \mathrm{~min}$ with $15 \mathrm{~min}$ intervals during the first hour followed by a single reading at $90 \mathrm{~min}$ after adding chemicals. Hach sulfide test kit was used to investigate the hydrogen sulfide concentration changes at specific intervals.
\end{abstract}

\section{Experimental methods}

Laboratory experiments were carried out using a $1.2 \mathrm{~L}$ container filled by $1000 \mathrm{ml}$ of the sample. The designed concentrations of the chemicals were then injected into the containers. The containers were sealed using rubber caps to prevent air from entering. To investigate the effect of $\mathrm{FeCl}_{3}$, it was mixed thoroughly in the sewage for $15 \mathrm{~min}$ when $\mathrm{Mg}(\mathrm{OH})_{2}$ and $\mathrm{Ca}(\mathrm{ClO})_{2}$ were added separately to the prepared mixed samples. Several concentrations of chemicals were examined in order to estimate their effective dosage. A $1.2 \mathrm{~L}$ container filled with untreated sewage was kept under the same condition of each experiment as the control sample during each step of tests. The mean values of a minimum of three measurements with less than 5\% error were analyzed and presented in this study.

\section{RESULTS AND DISCUSSION}

\section{Addition of chemicals individually}

Initial experiments were conducted to determine the effective concentration of designed chemicals when they 

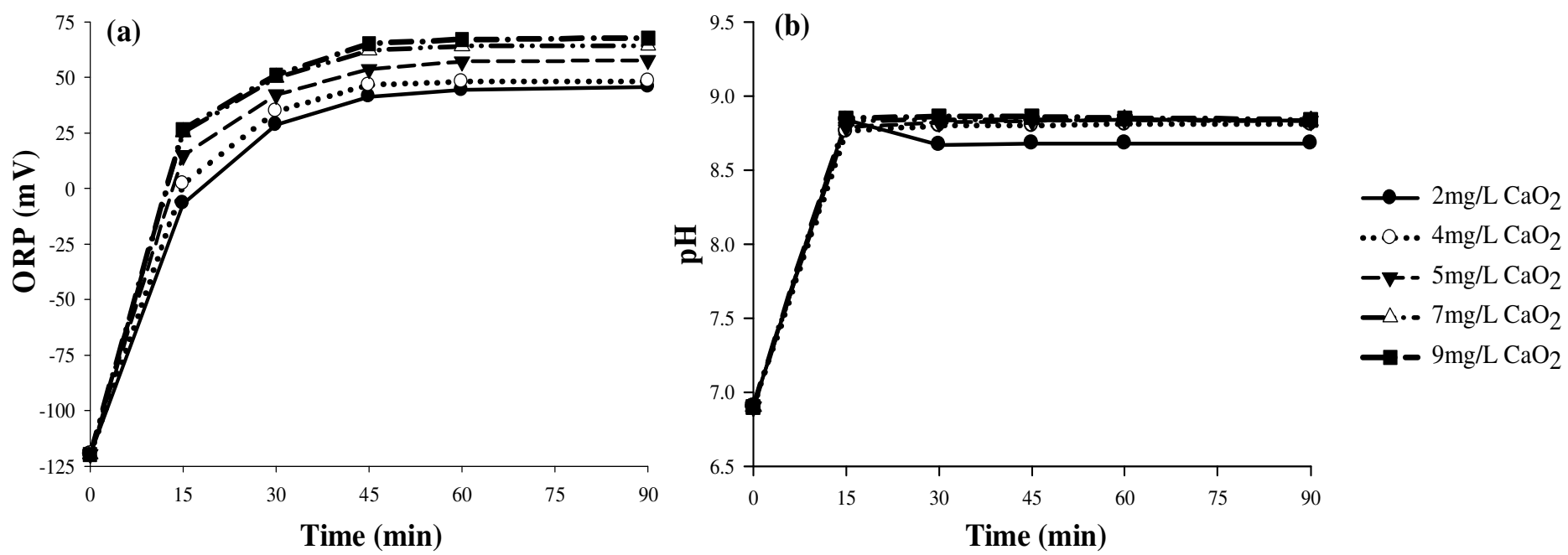

Figure 1. (a) ORP values and (b) $\mathrm{pH}$ values at different reaction times for different concentrations of added $\mathrm{CaO}_{2}$.

were added individually. The ORP was analyzed as an indicator whose relative changes can be used to interpret the effect of the applied SRB inhibition technique. In other words, increase in ORP is strongly related to the inhibition of SRB numbers; thus, ORP increment caused by chemical addition indicates a decrement in SRB activity and consequently cease on $\mathrm{H}_{2} \mathrm{~S}$ generation. This effort is agreed by the fact that ORP always rises after the SRB become extinct (Chang et al., 2008). The typically favorite range of ORP for SRB is defined by -50 to $-300 \mathrm{mV}$ (Edwards et al., 2001), furthermore, ORP above $50 \mathrm{mV}$ was reported to circumvent hydrogen sulfide generation due to SRB (Derek, 1995). Besides, the proportion of $\mathrm{H}_{2} \mathrm{~S}$ in sewage at a $\mathrm{pH}$ higher than 8 decreases to less than $10 \%$ of dissolved sulfides (Thistlethwayte, 1972). However, Jefferson et al. (2002) proposed that $\mathrm{pH}$ raise to levels above 9 leads to some problems such as sludge generation, ammonia gas evolution, and calcium carbonate precipitation.

Therefore, ORP $>50 \mathrm{mV}$ and $8.5 \leq \mathrm{pH} \leq 9$ were picked as the safe range of response to evaluate the experimental results for each designed value of additional chemical. Calcium peroxide $\left(\mathrm{CaO}_{2}\right)$ as inhibitor, will form hydrogen peroxide if in contact with acid while with water, it will immediately begin to decompose and releasing oxygen producing calcium hydroxide (Zhang et al., 2008). Chang et al. (2007) stated that $\mathrm{CaO}_{2}$ (solid-phase) is a slow oxygen releaser able to deplete the sulfide concentration in water. Reactions (4) and (5) depict production of base, generation of oxygen, and sulfide oxidation which can cause ORP and $\mathrm{pH}$ increment and SRB inhibition.

$\mathrm{CaO}_{2}+\mathrm{H}_{2} \mathrm{O} \rightarrow \mathrm{Ca}(\mathrm{OH})_{2}+1 / 2 \mathrm{O}_{2}$

$\mathrm{CaO}_{2}+\mathrm{H}_{2} \mathrm{~S}_{(\mathrm{aq})} \rightarrow \mathrm{CaS} \downarrow+\mathrm{H}_{2} \mathrm{O}_{2}$

Various concentrations $(2,4,5,7,9 \mathrm{mg} / \mathrm{L})$ of this chemical were examined until less than $5 \%$ changes was observed in ORP. Figure 1a, b show the changes in ORP and $\mathrm{pH}$ versus time after the addition of $\mathrm{CaO}_{2}$ by designed concentrations. It is revealed from Figure 1a that by the first $15 \mathrm{~min}$ the ORP had increased rapidly from $-120 \mathrm{mV}$ to a maximum value of $27 \mathrm{mV}$. Afterwards, the changes of ORP took place gently, and no significant change in ORP was observed after $45 \mathrm{~min}$. This indicates that most reaction of $\mathrm{CaO}_{2}$ happened for a period of 45 min. The efficient reaction time for $\mathrm{CaO}_{2}$ in sewage samples was $45 \mathrm{~min}$ after addition. At this time, concentration between 4 to $5 \mathrm{mg} / \mathrm{L}$ of this material is enough to increase the ORP to more than $50 \mathrm{mV}$. In this case, the ORP rose to a maximum of $54 \mathrm{mV}$. However, the ORP value increased to more than $50 \mathrm{mV}$ within the reaction time of $30 \mathrm{~min}$ when between 7 to $9 \mathrm{mg} / \mathrm{L}$ of $\mathrm{CaO}_{2}$ was used. Figure 2 shows more specifically, ORP values obtained for each concentration of $\mathrm{CaO}_{2}$ when reaction times were 45 (Equation 1) and 30 (Equation 2) min. Second order curves fitted data well and pertinent equations $\left(R^{2}>0.93\right)$ are:

$$
\begin{aligned}
& Y_{1}=3.6507 X_{1}+34.086 \\
& Y_{2}=3.4404 X_{2}+22.742
\end{aligned}
$$

where $Y_{1}$ and $Y_{2}$ are ORP in $m V$ and $X_{1}$ and $X_{2}$ are the $\mathrm{CaO}_{2}$ concentration in $\mathrm{mg} / \mathrm{L}$.

Figure $1 \mathrm{~b}$ shows that the $\mathrm{pH}$ changed quickly for the first 15 min (from pH 6.9 to about 8.9); while it remained at the safe range and there were no considerable changes afterwards. The results were similar for different concentrations of $\mathrm{CaO}_{2}$ except for the case of adding 2 $\mathrm{mg}$ of $\mathrm{CaO}_{2} / \mathrm{L}$, the $\mathrm{pH}$ increased to its maximum at 8.9, 


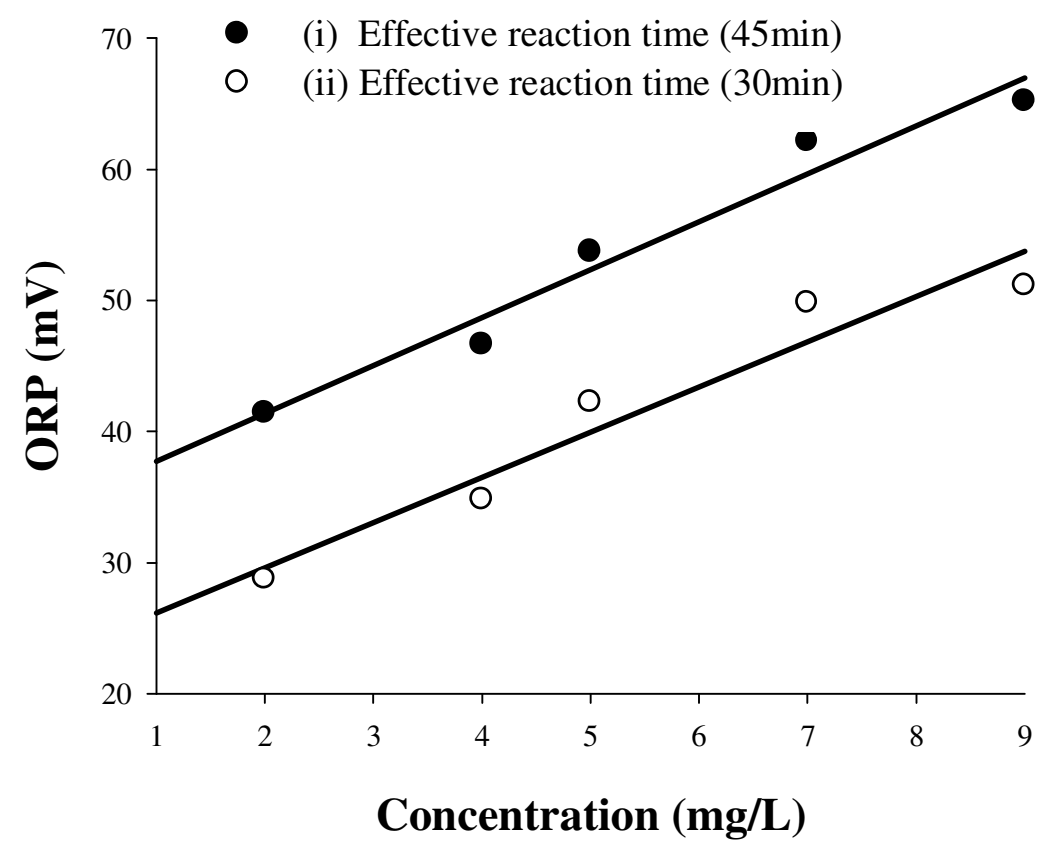

Figure 2. ORP achieved using effective $\mathrm{CaO}_{2}$ concentration within reaction times (i) $30 \mathrm{~min}$ and (ii) $45 \mathrm{~min}$.

Table 2. Applied concentrations of the selected chemical and achieved optimum concentrations.

\begin{tabular}{lccccc}
\hline Chemical & $\begin{array}{c}\text { Designed } \\
\text { concentration (mg/L) }\end{array}$ & $\begin{array}{c}\text { ORP changes } \\
\text { Min - Max (mV) }\end{array}$ & $\begin{array}{c}\text { pH changes } \\
\text { Min - Max }\end{array}$ & $\begin{array}{c}\text { Efficient reaction time } \\
\text { (min) }\end{array}$ & $\begin{array}{c}\text { Optimum concentration } \\
\text { (mg/L) }\end{array}$ \\
\hline $\mathrm{CaO}_{2}$ & $2,4,5,7,9$ & $-120-65$ & $6.9-8.9$ & 45 & 4.4 \\
$\mathrm{Mg}(\mathrm{OH})_{2}$ & $4,6,8,10,12,14$ & $-120-139$ & $6.9-9.1$ & 30 & 10.6 \\
$\mathrm{Ca}(\mathrm{ClO})_{2}$ & $6,8,10,12,15,25$ & $-120-132$ & $6.9-8.8$ & 30 & 13.3 \\
$\mathrm{FeCl}_{3}$ & $4,6,8,10,12,14$ & $-120-143$ & $6.9-6.7$ & 30 & 8 \\
\hline
\end{tabular}

but after 15 min of reaction it dropped to 8.7. The reason for the $\mathrm{pH}$ dropping after $15 \mathrm{~min}$ is difficult to explain as it has not been reported elsewhere. This may be due to the reaction of low concentration of $\mathrm{CaO}_{2}$ with soluble compounds in sewage.

However, this does not have a significant effect as the $\mathrm{pH}$ safe range is 8.5 and above. The optimum values predicted by Equations 1 and 2 were 4.4 and $8.0 \mathrm{mg} / \mathrm{L}$ for $\mathrm{CaO}_{2}$ concentration which would result in $\mathrm{ORP} \geq 50 \mathrm{mV}$ during 45 and $30 \mathrm{~min}$ reaction time. Subsequent experiments using the predicted values confirmed that the safe value of ORP $(50,51,53 \mathrm{mV})$ and $\mathrm{pH} 8.8 \pm 0.1$ were obtained. A similar investigation was conducted to determine the effective concentration of $\mathrm{Mg}(\mathrm{OH})_{2}$, $\mathrm{Ca}(\mathrm{ClO})_{2}$, and $\mathrm{FeCl}_{3}$ chemicals individually. The results obtained were compared with those achieved from using $\mathrm{CaO}_{2}$ in Table 2. Table 2 lists the designed concentrations, the range of ORP and $\mathrm{pH}$, and the effective doses and time for each chemical. Magnesium hydroxide $\left(\mathrm{Mg}(\mathrm{OH})_{2}\right)$ is used industrially as a nonhazardous alkali to neutralize acidic wastewaters and raise the $\mathrm{pH}$ up to 10.0 . This $\mathrm{pH}$ level can deactivate the bacteria responsible for the acid generation, since they cannot tolerate the high $\mathrm{pH}$ conditions (Jefferson et al., 2002). Since $\mathrm{Mg}(\mathrm{OH})_{2}$ is a strong base, increase in $\mathrm{pH}$ was observed. This chemical also raised the ORP value. Due to its low solubility in water, it mostly react with $\mathrm{H}_{2} \mathrm{~S}_{(a \mathrm{q})}$. The precipitation of $\mathrm{H}_{2} \mathrm{~S}_{(\mathrm{aq})}$ is shown in the following reaction.

$$
\mathrm{Mg}(\mathrm{OH})_{2}+\mathrm{H}_{2} \mathrm{~S}_{(\mathrm{aq})} \rightarrow \mathrm{MgS} \downarrow+2 \mathrm{H}_{2} \mathrm{O}
$$

The ORP increased from minimum $-120 \mathrm{mV}$ to a maximum of $139 \mathrm{mV}$. The $\mathrm{pH}$ also raised from 6.9 to 9.1 . The effective reaction time and obtained optimum concentration of $\mathrm{Mg}(\mathrm{OH})_{2}$ were estimated as 30 min and $10.6 \mathrm{mg} / \mathrm{L}$, respectively. It is reported as a major disadvantage that $\mathrm{Mg}(\mathrm{OH})_{2}$ cannot remove the sulfide completely from the water. In such way, odor formation will occur if the $\mathrm{pH}$ is decreased in any consequent point in the sewage treatment process (Jefferson et al., 2002). Calcium hypochlorite $\left(\mathrm{Ca}(\mathrm{ClO})_{2}\right)$ is identified as a strong 
Table 3. The designed combined chemicals' concentrations.

\begin{tabular}{cc}
\hline Combination no. & Materials \\
\hline 1 & $2.0 \mathrm{mg} / \mathrm{L} \mathrm{FeCl}_{3}$ and $2.5 \mathrm{mg} / \mathrm{L} \mathrm{Mg}(\mathrm{OH})_{2}$ \\
2 & $2.0 \mathrm{mg} / \mathrm{L} \mathrm{FeCl}_{3}$ and $4.0 \mathrm{mg} / \mathrm{L} \mathrm{Mg}(\mathrm{OH})_{2}$ \\
3 & $3.0 \mathrm{mg} / \mathrm{L} \mathrm{FeCl}_{3}$ and $2.5 \mathrm{mg} / \mathrm{L} \mathrm{Mg}(\mathrm{OH})_{2}$ \\
4 & $3.0 \mathrm{mg} / \mathrm{L} \mathrm{FeCl}_{3}$ and $4.0 \mathrm{mg} / \mathrm{L} \mathrm{Mg}(\mathrm{OH})_{2}$ \\
5 & $2.0 \mathrm{mg} / \mathrm{L} \mathrm{FeCl}_{3}$ and $3.0 \mathrm{mg} / \mathrm{L} \mathrm{Ca}(\mathrm{ClO})_{2}$ \\
6 & $2.0 \mathrm{mg} / \mathrm{L} \mathrm{FeCl}_{3}$ and $5.0 \mathrm{mg} / \mathrm{L} \mathrm{Ca}(\mathrm{ClO})_{2}$ \\
7 & $3.0 \mathrm{mg} / \mathrm{L} \mathrm{FeCl}_{3}$ and $3.0 \mathrm{mg} / \mathrm{L} \mathrm{Ca}(\mathrm{ClO})_{2}$ \\
8 & $3.0 \mathrm{mg} / \mathrm{L} \mathrm{FeCl}_{3}$ and $5.0 \mathrm{mg} / \mathrm{L} \mathrm{Ca}(\mathrm{ClO})_{2}$ \\
\hline
\end{tabular}

oxidizer chemical that can be used for hydrogen sulfide oxidation (Zhang et al., 2008). Results also showed that $\mathrm{Ca}(\mathrm{ClO})_{2}$ increased the ORP and $\mathrm{pH}$ values (Table 2). This chemical is soluble in water; thus, the chemical reaction (4) will take place in the mixture showing the production of a strong base $\left(\mathrm{Ca}(\mathrm{OH})_{2}\right)$. This strong base reacts with aqueous $\mathrm{H}_{2} \mathrm{~S}$ and oxidizes it (chemical reaction (5)). The reaction time was $30 \mathrm{~min}$ and the optimum concentration of this chemical was estimated as $13.3 \mathrm{mg} / \mathrm{L}$. Researchers reported advantages for $\mathrm{Ca}(\mathrm{ClO})_{2}$ as a strong oxidizer such as high removal efficiency for $\mathrm{H}_{2} \mathrm{~S}$ and other organic compounds as well as odor control (Tomar and Abdullah, 1994; Cadena and Petters, 1988); however, some drawbacks are associated with this reagent e.g. steel corrosion in concrete structures (Derek, 1995).

$$
\begin{aligned}
& \mathrm{Ca}(\mathrm{ClO})_{2}+2 \mathrm{H}_{2} \mathrm{O} \rightarrow \mathrm{Ca}(\mathrm{OH})_{2}+2 \mathrm{HClO} \\
& \mathrm{Ca}(\mathrm{OH})_{2}+\mathrm{H}_{2} \mathrm{~S}_{(\mathrm{aq})} \rightarrow \mathrm{CaS} \downarrow+2 \mathrm{H}_{2} \mathrm{O}
\end{aligned}
$$

The wide use of iron salts mostly $\mathrm{FeCl}_{3}$ in wastewater industries means that they have become an effective chemical in sulfide control (Tomar and Abdullah, 1994; Padival et al., 1995; Firer et al., 2008). $\mathrm{FeCl}_{3}$ increased the ORP well (Table 2). However, results showed a little $\mathrm{pH}$ reduction which may be caused due to the acid phase production (chemical reaction (6)). Several pros and cons were reported for $\mathrm{FeCl}_{3}$, some of which are: long-duration control, cost effectiveness, non-oxidation of any other odorous compounds apart from sulfides, effect on alkalinity, depletion of dissolved oxygen, and solids production (Poulton et al., 2002; Walton et al., 2003).

$2 \mathrm{FeCl}_{3}+3 \mathrm{H}_{2} \mathrm{~S}_{(\mathrm{aq})} \rightarrow \mathrm{Fe}_{2} \mathrm{~S}_{3} \downarrow+6 \mathrm{HCl}$

Table 2 summarizes the experimental results for the aforementioned chemicals. The safe range of ORP $(\geq 50$ $\mathrm{mV}$ ) was experienced for all the chemicals, but at different concentrations. The lowest reagent concentration was achieved for $\mathrm{CaO}_{2}$ but the sufficient reaction time was longer than others. However, higher concentrations of $\mathrm{CaO}_{2}$ were examined aiming to achieve the same effective reaction time $(30 \mathrm{~min})$, and $8.0 \mathrm{mg} / \mathrm{L}$ was found satisfactory, which is smaller than the optimum values for the other chemicals. Additionally, a poor $\mathrm{pH}$ increment by $\mathrm{FeCl}_{3}$, and extremely high $\mathrm{pH}$ was observed when $\mathrm{Mg}(\mathrm{OH})_{2}$ was utilized; however calcium compositions resulted in a satisfactory $\mathrm{pH}$ in the medium. The optimum concentration was predicted by the models generated (similar to Equations 1 and 2) from the experimental results and subsequent experiments approved their accuracy (as explained for $\mathrm{CaO}_{2}$ ).

\section{Addition of the combination of chemicals}

A combination of chemical materials may result in lower dosage and higher efficiency in circumventing hydrogen sulfide concentration, and thus, alleviation in the drawbacks associated with chemicals is probable. As such, combination of $\mathrm{FeCl}_{3}$ with $\mathrm{Mg}(\mathrm{OH})_{2}$ or $\mathrm{Ca}(\mathrm{ClO})_{2}$ to sewage was surveyed. As discussed, $\mathrm{FeCl}_{3}$ reacts with sewage and produced $\mathrm{HCl}$ (acid compound) which acts as a $\mathrm{pH}$ decrement reagent. $\mathrm{Mg}(\mathrm{OH})_{2}$ or $\mathrm{Ca}(\mathrm{ClO})_{2}$ can react with the generated $\mathrm{HCl}$ and neutralize the solution (chemical reactions 7 and 8). Thus, it is expected that a proper combination of these chemicals regulate the resulted ORP and $\mathrm{pH}$ in the safe range.

$$
\begin{aligned}
& 2 \mathrm{FeCl}_{3}+3 \mathrm{Mg}(\mathrm{OH})_{2}+3 \mathrm{H}_{2} \mathrm{~S}_{(\mathrm{aq})} \rightarrow \mathrm{Fe}_{2} \mathrm{~S}_{3} \downarrow+3 \mathrm{MgCl}_{2} \downarrow+6 \mathrm{H}_{2} \mathrm{O}(7) \\
& 4 \mathrm{FeCl}_{3}+3 \mathrm{Ca}(\mathrm{ClO})_{2}+3 \mathrm{H}_{2} \mathrm{~S}_{(\mathrm{aq})} \rightarrow \\
& 2 \mathrm{Fe}_{2} \mathrm{~S}_{3} \downarrow+3 \mathrm{CaCl}_{2} \downarrow+6 \mathrm{Cl}_{2}+6 \mathrm{H}_{2} \mathrm{O}
\end{aligned}
$$

Accordingly, the designed concentrations of these materials ( 25 and $37.5 \%$ of obtained optimum doses) were examined as shown in Table 3. For this experiment, $\mathrm{FeCl}_{3}$ was added first, followed by the second chemical 15 min later. Figure $3 a$ shows the ORP values versus time for the combination of $\mathrm{FeCl}_{3}$ and $\mathrm{Mg}(\mathrm{OH})_{2}$ with different combinations (1 to 4). It can be seen from the Figure that ORP increased sharply from $-120 \mathrm{mV}$ to the safe region within the first $15 \mathrm{~min}$ (to a maximum of 61 $\mathrm{mV}$ ). After adding $\mathrm{Mg}(\mathrm{OH})_{2}$, ORP rose more gently and reached its maximum at $90 \mathrm{~min}$. It can be seen from Figure $3 a$ that 30 min after adding $\mathrm{Mg}(\mathrm{OH})_{2}$ (time point 45 min), no significant changes in ORP were observed. The $\mathrm{pH}$ vs. time is shown in Figure $3 \mathrm{~b}$ and it can be concluded that adding $\mathrm{FeCl}_{3}$ to the sewage samples caused a slight drop in the $\mathrm{pH}$ within the first $15 \mathrm{~min}$. As mentioned previously, this little decrement might be due to production of $\mathrm{HCl}$ (acid phase).

However, addition of $\mathrm{Mg}(\mathrm{OH})_{2}$ to the mixed samples within reaction time of $15 \mathrm{~min}$ (time point $30 \mathrm{~min}$ ) increased the $\mathrm{pH}$ rapidly from about 6.8 to about 8.7 . Results showed that combinations (1) and (2) resulted in $\mathrm{pH}$ increment to the safe range (that is 8.6 and 8.7, respectively). It can be concluded that the combination (1) is the most efficient combination resulting into ORP 78 $\mathrm{mV}$ and $\mathrm{pH} 8.6$ within 30 min reaction time since it is using less chemicals. Similar outcomes resulted by 

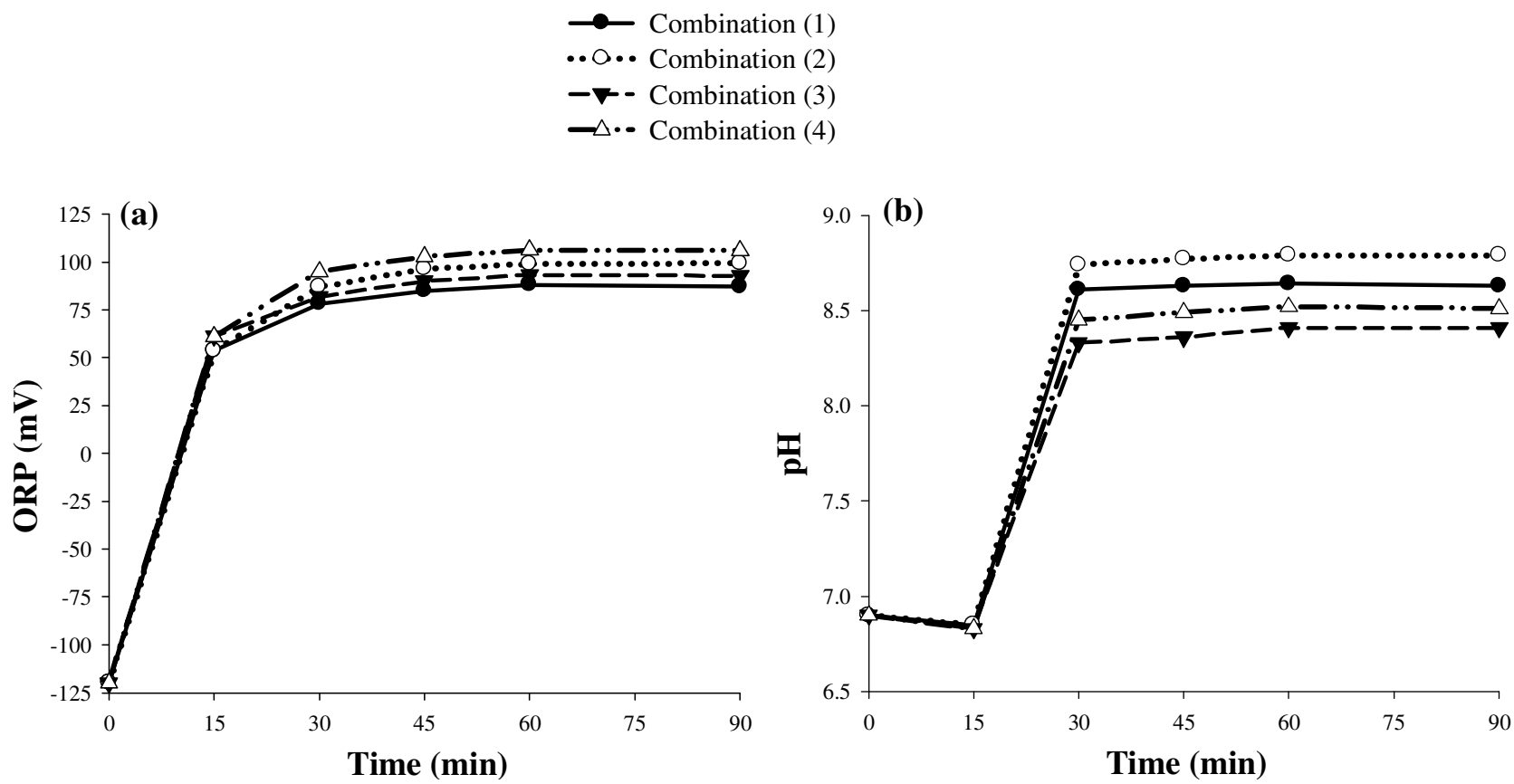

Figure 3. (a) ORP values and (b) $\mathrm{pH}$ values observed at different reaction times when different concentrations of $\mathrm{FeCl}_{3}$ and $\mathrm{Mg}(\mathrm{OH})_{2}$ were added to sewage.
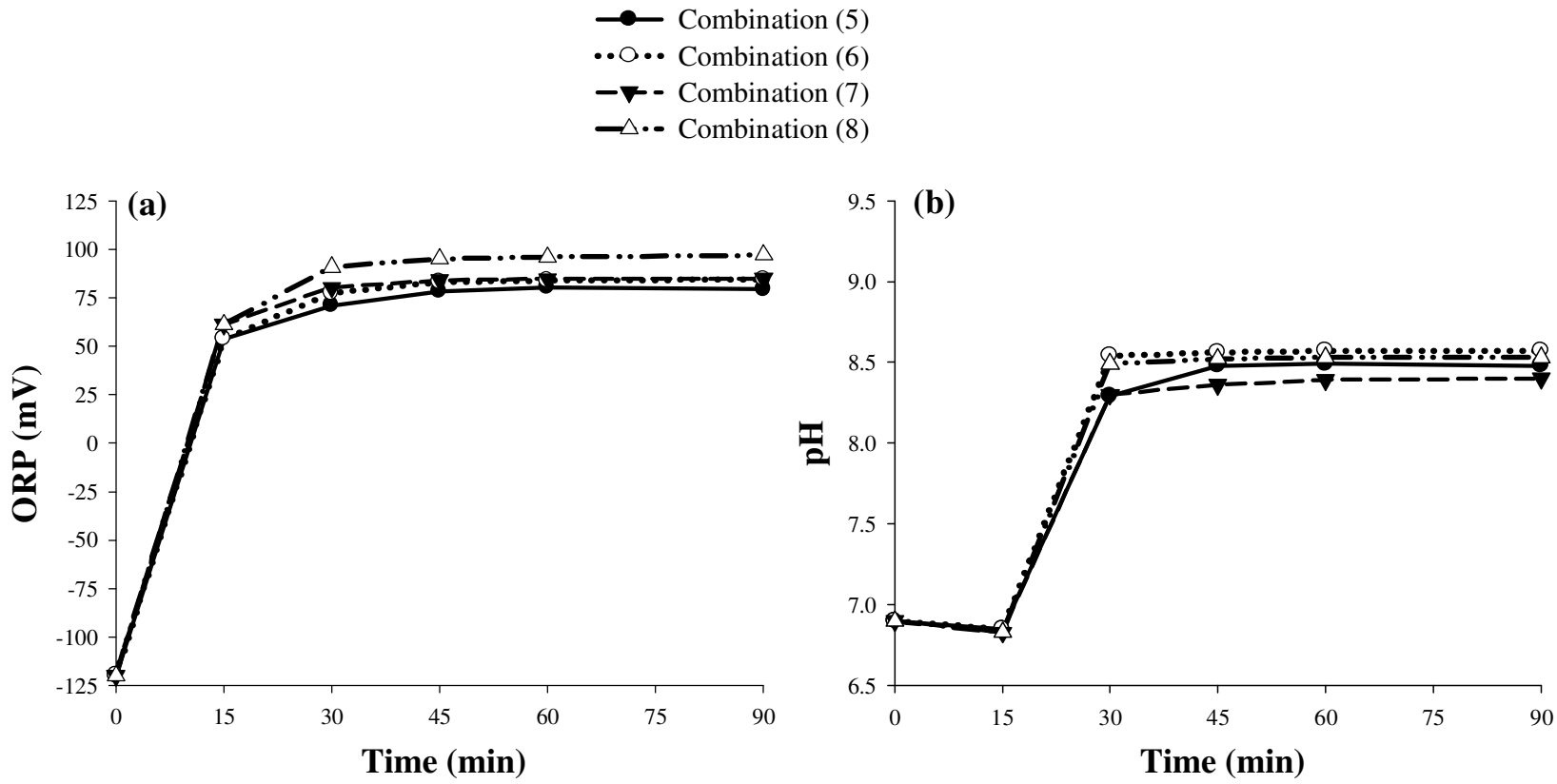

Figure 4. (a) ORP values and (b) $\mathrm{pH}$ values observed at different reaction times when different concentrations of $\mathrm{FeCl}_{3}$ and $\mathrm{Ca}(\mathrm{ClO})_{2}$ were added to sewage.

adding combinations of $\mathrm{FeCl}_{3}-\mathrm{Ca}(\mathrm{ClO})_{2}$ to the sewage samples (combinations 5 to 8 ). Figure $4 a$ demonstrates that the designed concentrations of $\mathrm{FeCl}_{3}-\mathrm{Ca}(\mathrm{ClO})_{2}$ increased the ORP from a minimum of $-120 \mathrm{mV}$ to a maximum of $91 \mathrm{mV}$ at the first $30 \mathrm{~min}$ of addition (time point $45 \mathrm{~min}$ ), and marginal changes in ORP were observed onwards (ORP increased to maximum $97 \mathrm{mV}$ ). Figure $4 \mathrm{~b}$ illustrates alteration in $\mathrm{pH}$ versus time, and it can be seen that only combinations (6) and (8) were successful in raising the $\mathrm{pH}$ to the safe range. Combination (6) raised the $\mathrm{pH}$ from 6.9 to a maximum value of 8.6 , while combination (8) shifted the same initial 
Table 4. Cost estimation for daily treatment of sewage using efficient dose of chemicals.

\begin{tabular}{|c|c|c|c|c|c|}
\hline Chemical & $\begin{array}{l}\text { Effective reaction } \\
\text { time (min) }\end{array}$ & $\begin{array}{l}\text { Obtained effective } \\
\text { concentration (mg/L) }\end{array}$ & Price (US\$/g) & $\begin{array}{c}\text { Cost } \\
\text { (US\$/day) }\end{array}$ & Rate \\
\hline $\mathrm{CaO}_{2}$ & 45 & 4.4 & 0.056 & 118 & 2 \\
\hline $\mathrm{CaO}_{2}$ & 30 & 8.0 & 0.056 & 215 & 5 \\
\hline $\mathrm{Mg}(\mathrm{OH})_{2}$ & 30 & 10.6 & 0.050 & 254 & 6 \\
\hline $\mathrm{Ca}(\mathrm{ClO})_{2}$ & 30 & 13.3 & 0.048 & 306 & 7 \\
\hline $\mathrm{FeCl}_{3}$ & 30 & 8 & 0.047 & 180 & 4 \\
\hline${ }^{*} \mathrm{FeCl}_{3}$ and $\mathrm{Mg}(\mathrm{OH})_{2}$ & 30 & 2 and 2.5 & $0.047-0.050$ & 105 & 1 \\
\hline${ }^{* *} \mathrm{FeCl}_{3}$ and $\mathrm{Ca}(\mathrm{ClO})_{2}$ & 30 & 2 and 5 & $0.047-0.048$ & 160 & 3 \\
\hline
\end{tabular}

${ }^{*}$ Combination (1), ${ }^{* *}$ Combination (6).

$\mathrm{pH}$ to 8.5. After the efficient reaction time (30 $\mathrm{min}) \mathrm{pH}$ remained steady. Thus, combinations (6) and (8) could satisfy $\mathrm{H}_{2} \mathrm{~S}$ circumvention within 30 min.

However, considering less chemical consumption, the combination (6) was selected as the most efficient set leading to ORP $77 \mathrm{mV}$ and $\mathrm{pH}$ 8.5. No considerable changes in ORP and $\mathrm{pH}$ were observed for the control sample with no chemical addition during the test procedure. Besides, as the temperature is quite significant in corrosion process and odor release in sewer networks, temperature was monitored throughout the experiments and no considerable change was detected due to adding chemicals. The average of initial hydrogen sulfide concentration in the sewage samples was $4 \mathrm{mg} / \mathrm{L}$. Analyses revealed that combinations (1) and (6) decreased the hydrogen sulfide concentration higher than $95 \%$. Using 4.4 and $8.0 \mathrm{mg} \mathrm{CaO} / \mathrm{L}$, hydrogen sulfide removal greater than $90 \%$ was measured for reaction times of 45 and $30 \mathrm{~min}$, respectively.

\section{Cost evaluation}

A wide diversity in treatment costs reflects the unique aspects of each chemical that may be warranted for a special program in which economics is the dominant selection criterion. Therefore, chemical costs should be estimated for a real scale of wastewater system, and Equation (3) helped to analyze the estimations for each selected chemical with their effective doses;

$$
\mathrm{C}_{\text {chemical }}=\left(\sum_{\mathrm{i}=1}^{\mathrm{n}}\left(\mathrm{M}_{\mathrm{i}} \times \mathrm{P}_{\mathrm{i}}\right)\right) \times \mathrm{Q}_{\mathrm{N}}
$$

Where $\mathrm{C}_{\text {chemical }}$ is cost of the chemicals (US $\$ /$ day), $\mathrm{M}_{\mathrm{i}}$ represents dose of the chemical $(\mathrm{mg} / \mathrm{L}), P_{i}$ is unit price of the chemical (US\$/g), and $Q_{N}$ is the sewage discharge (field study network outlet discharge was estimated by approximately $480 \mathrm{~m}^{3} /$ day). It is apparent from the equation that costs are dependent on dosage of chemicals and unit prices in the Malaysian market. Table
4 lists the estimated costs for the efficient dose of chemicals achieved in this work based on the market material prices provided by the chemical supplier (2008). It can be seen from Table 4 that the least cost was obtained when $\mathrm{FeCl}_{3}$ and $\mathrm{Mg}(\mathrm{OH})_{2}$ were used (combination 1). It is about 12 and $53 \%$ more cost effective than using $\mathrm{CaO}_{2}$ alone and $\mathrm{FeCl}_{3}$ and $\mathrm{Ca}(\mathrm{ClO})_{2}$ (combination 6), respectively.

\section{Conclusions}

Different chemicals and their combinations were added to sewage at various concentrations for inhibition of dissolved $\mathrm{H}_{2} \mathrm{~S}$ in sewer systems. Experiments applying chemicals individually showed $\mathrm{CaO}_{2}$ resulted in lower concentration of chemical rather than $\mathrm{FeCl}_{3}, \mathrm{Mg}(\mathrm{OH})_{2}$, and $\mathrm{Ca}(\mathrm{ClO})_{2}$ to satisfy ORP and $\mathrm{pH}$ ranges in the medium. Addition of $4.4 \mathrm{mg} / \mathrm{L} \mathrm{CaO}_{2}$ with 45 min reaction time was the most economical case amongst individually added chemicals. However, results obtained from application of chemical combinations indicate that the 2 $\mathrm{mg} / \mathrm{L} \mathrm{FeCl}_{3}$ plus $2.5 \mathrm{mg} / \mathrm{L} \mathrm{Mg}(\mathrm{OH})_{2}$ and also $2 \mathrm{mg} / \mathrm{L}$ $\mathrm{FeCl}_{3}$ plus $5 \mathrm{mg} / \mathrm{L} \mathrm{Ca}(\mathrm{ClO})_{2}$, resulted in the safe ranges of ORP and $\mathrm{pH}$ with lower operational costs rather than utilizing chemicals individually within $30 \mathrm{~min}$ reaction time. Furthermore, reduction for dissolved $\mathrm{H}_{2} \mathrm{~S}$ in sewage at a rate higher than $95 \%$ was obtained through application of these chemical combinations.

\section{ACKNOWLEDGEMENTS}

The authors gratefully acknowledge the cooperation of the Indah Water Konsortium (IWK) and financial support from the University of Malaya in carrying out this work.

\section{REFERENCES}

ASCE (1989). Sulfide in wastewater collection and treatment systems, Manuals and Reports on Engineering Practice Am. Soc. Civil Eng, New York., p. 69.

Cadena F, Petters RW (1988). Evaluation of chemical oxidizers for 
hydrogen sulfide control. J. Water Pollut. Contr. Fed., 60(7): 1259-1263.

Chang YJ, Chang YT, Chen HJ (2007). A method for controlling hydrogen sulfide in water by adding solid phase oxygen. Bioresource Technol., 98(2): 478-483.

Chang YJ, Chang YT, Hung CH (2008). The use of magnesium peroxide for the inhibition of sulfate-reducing bacteria under anoxic conditions. J. Ind. Microbiol. Biot., 35(11): 1481-1491.

De Lomas JG, Corzo A, Gonzalez JM, Andrades JA, Iglesias E, Montero MJ (2005). Nitrate promotes biological oxidation of sulfide in wastewaters: experiment at plant-scale. Biotechnol. Bioeng., 93(4): 801-811.

Delgado S, Alvarez M, Rodriguez-Gomez LE, Aguiar E (1999). $\mathrm{H}_{2} \mathrm{~S}$ generation in a reclaimed urban wastewater. Water Res., 33(2): 539547.

Derek CWS (1995). The control of septicity and odors in sewerage systems and at sewage treatment works operated by Anglian water service limited. Water Sci. Technol., 31(7): 283-292.

Edwards VA, Velasco CP, Edwards KJ (2001). Hydrogen sulfide - The relationship of bacteria to its formation, prevention, and elimination. www.alken-murray.com/h2srem2.htm. Accessed 5 November 2008.

Elmaleh S, Delgado S, Alvarez M, Rodriguez-Gomez LE, Aguilar E (1998). Forecasting of $\mathrm{H}_{2} \mathrm{~S}$ build-up in a reclaimed wastewater pipe. Water Sci. Technol., 38(10): 241-248.

Firer D, Friedler E, Lahav O (2008). Control of sulfide in sewer systems by dosage of iron salts: comparison between theoretical and experimental results and practical implications. Sci. Total Environ., 392(1): 145-156.

Hobson J, Yang G (2000). The ability of selected chemicals for suppressing odor development in rinsing mains. Water Sci. Technol., 41(6): 165-173.

Jefferson B, Hurst A, Stuetz R, Parsons SA (2002). Comparison of chemical methods for the control of odors in wastewater process. Process Saf. Environ. Protect., 80(2): 93-99.

Nemati M, Mazutinec TJ, Jenneman GE, Voordouw G (2001). Control of biogenic $\mathrm{H}_{2} \mathrm{~S}$ production with nitrate and molybdate. J. Ind. Microbiol. Biot., 26(6): 350-355.

Nielsen AH, Vollertsen J, Hvitved-Jacobsen T (2005). Kinetics and stoichiometry of sulfide oxidation by sewer biofilms. Water Res., 39(12): 4119-4125.

Nielsen PH, Raunkjaer K, Hvitved-Jacobsen T (1998). Sulfide production and wastewater quality in pressure mains. Water Sci. Technol., 37(1): 97-104.

Padival NA, Kimbell WA, Redner JA (1995). Use iron salts to control dissolved sulfide in trunk sewers. J. Environ. Eng., 121(11): 824-829.
Poulton WS, Krom MD, Rijn JV, Raiswell R (2002). The use of hydrous iron (III) oxides for the removal of hydrogen sulfide in aqueous systems. Water Res., 36(4): 825-834.

Thistlethwayte DKB (1972). The Control of Sulfides in Sewerage System, $1^{\text {st }}$ Ed., Ann Arbor Science Publishers Inc, Michigan, pp. 159-173.

Tomar M, Abdullah THA (1994). Evaluation of chemicals to control the generation of malodorous hydrogen sulfide in wastewater. Water Res., 28(12): 2542-2552.

US Environmental Protection Agency (1974). Process Design Manual for Sulfide Control in Sanitary Sewerage Systems. United States Environmental Protection Agency Technology Transfer office, Washington, DC, EPA-625/1-74-005.

Walton JR, Velasco MS, Ratledge ED (2003). Peroxide regenerated iron-sulfide control (PRI-SC) TM: Integrating collection system sulfide control with enhanced primary clarification by adding iron salts and hydrogen peroxide. In WEFTEC 2003 Water Environment Foundation, Virginia, USA, pp. 282-307.

WERF (Water Environment Research Foundation) (2003). Identifying and controlling odor in the municipal wastewater environment. Phase $\mathrm{I}$ : literature search and review. Water Environment Federation Publisher, Virginia, USA, Project No. 00-HHE-5A.

Witherspoon J, Allen E, Quigley C (2004). Modeling to assist in wastewater collection system odor and corrosion potential evaluations. Water Sci. Technol., 50(4): 177-183.

Zhang L, De Schryver P, De Gusseme B, De Muynck W, Boon N, Verstracte W (2008). Chemical and biological technologies for hydrogen sulfide emission control in sewer systems: A review. Water Res., 42(1-2): 1-12. 